\title{
Body mass index increases CD4+ count in HIV/AIDS patients on first-line therapy
}

\author{
Mirna Widiyanti*, Moch Irfan Hadi**, Mei Lina Fitri Kumalasari****, \\ Evi Iriani Natalia*, Dedi Purba*, and Setyo Adiningsih*
}

\begin{abstract}
BACKGROUND

The body mass index (BMI) may contribute somewhat to drug metabolism, thus affecting the efficacy of antiretroviral therapy (ART). CD $4^{+}$counts in people infected with HIV are essential in determining the stage of the disease, initiation of antiretroviral therapy, opportunistic infections and evaluating treatment outcomes. The aim of this study was to determine the association of BMI and clinical stage with $\mathrm{CD}^{+}$counts in $\mathrm{HIV}$ patients seeking treatment using first-line antiretroviral therapy (ART).
\end{abstract}

\section{METHODS}

An analytic study with a cross-sectional approach was conducted involving $251 \mathrm{HIV} / A I D S$ patients who had received first-line antiretrovirals over six months. BMI, clinical staging according to WHO and CD4 + were collected. Multiple linear regression was used to evaluate the relationship between BMI, clinical stage and CD4+.

\section{RESULTS}

Among the enrolled patients, the median age was 36 years, $135(55 \%)$ of the patients was female, $102(40.6 \%)$ was overweight/obese, $161(64.1 \%)$ was in stage 3 of the disease, and the median CD4 ${ }^{+}$count was 389 cells/ $\mathrm{mm}^{3}$. Multiple linear regression test showed two variables with a significant effect on CD4+ count, namely BMI (B=69.247; $95 \% \mathrm{CI}: 42.886-95.608)$ and clinical stage $(B=61.590 ; 28.910-94.270)$. BMI was the most influencing factor for $\mathrm{CD} 4+\operatorname{count}(\beta=0.307)$ compared to clinical stage $(\beta=0.216)$.

\section{CONCLUSIONS}

Body mass index was the most influencing factor for CD4 + counts of HIV/ AIDS patients. Regular ART can increase $\mathrm{CD}^{+}$counts and maintain the health of HIV/AIDS patients.

Keywords: CD4 + count, body mass index, clinical staging, HIV patients
*Centre for Papua Health Research and Development,

Ministry of Health, Republic of Indonesia **Faculty of Science and Technology, Universitas Islam Negeri Sunan Ampel, Surabaya ***Faculty of Psychology and Health Sciences, Universitas Islam Negeri Sunan Ampel, Surabaya

\section{Correspondence:}

Mirna Widiyanti

Centre for Papua Health Research and Development, Ministry of Health, Republic of Indonesia Phone: +6281344388000 Email: ninawidhy@gmail.com ORCID ID: 0000-0001-8246-7672

Date of first submission, June 19, 2020 Date of final revised submission, August 12, 2020

Date of acceptance, August 13, 2020

This open access article is distributed under a Creative Commons AttributionNon Commercial-Share Alike 4.0 International License

Cite this article as: Widiyanti M, Hadi MI, Kumalasari MLF, Natalia EI, Purba $\mathrm{D}$, Adiningsih $\mathrm{S}$. Body mass index increases CD4+ count in HIV/AIDS patients on first-line therapy. Univ Med 2020;39:121-7. doi: 10.18051/ UnivMed.2020. v39.121-127 


\section{INTRODUCTION}

HIV/AIDS is a global health problem, with the number of cases to date reaching 32 million. Increased access to effective prevention, diagnosis, treatment and care makes this disease manageable and allows people living with HIV (PLHIV) to live healthier lives. At the end of 2018 there were around 37.9 million people living with HIV and 1.7 million new cases of infection. $^{(1)}$

The latest data in 2019 show that the numbers of HIV and AIDS cases in Papua Province were 34,473 and 22,554 respectively, while in the Province of West Papua there were 5,243 and 1,741 cases, respectively. (2) This remains a challenge in the prevention and control of HIV/AIDS in Papua, especially in West Papua. West Papua Province as of September 2016 had 5,839 cases, where the highest number of cases was in Manokwari District with 1,422 cases, followed by Sorong City with 1,902 cases, Sorong District with 1,026 cases, and Fak-Fak District with 423 cases. ${ }^{(3)}$ This led us to consider making Manokwari Regency, Sorong City and Fak-Fak Regency our research sites in West Papua Province.

The measurement of body weight is an important evaluation in diagnosing HIV. Low body mass index (BMI) is the first criteria in defining AIDS. In addition, BMI also plays a role in determining WHO clinical stage, which includes weight loss, where weight loss of $<10 \%$ is categorized as stage 2 , while a weight loss of $>10 \%$ or a body mass index of $\leq 18.5 \mathrm{~kg} / \mathrm{m}^{2}$ is included in stage 3, and the HIV wasting syndrome falls into the clinical category of stage 4. (4)

The body mass index of HIV patients is an important predictor of antiretroviral outcomes ${ }^{(5-}$ ${ }^{7)}$ including prediction of CD4 cell changes ${ }^{(8)}$ and death. ${ }^{(9-11)}$ Negative changes in a patient's BMI are also independent predictors of dropout from HIV care cases. ${ }^{(12)}$ The BMI of HIV patients is influenced by gender, WHO stage ${ }^{(13)}$, duration of treatment, ${ }^{(14-15)}$ and CD4 cell count. ${ }^{(16)}$
World Health Organization (WHO) classifies body mass index by dividing the BMI value into underweight $\left(<18.5 \mathrm{~kg} / \mathrm{m}^{2}\right)$, normal weight $\left(18.5-24.9 \mathrm{~kg} / \mathrm{m}^{2}\right)$, pre-obesity $(25-29.9 \mathrm{~kg} /$ $\left.\mathrm{m}^{2}\right)$, obesity $\left(30-39.9 \mathrm{~kg} / \mathrm{m}^{2}\right)$, and morbid obesity $\left(>40 \mathrm{~kg} / \mathrm{m}^{2}\right){ }^{(17)}$

One study found that a higher BMI is associated with more robust CD4+ T-cell recovery in HAART-treated patients. ${ }^{(18)}$ CrumCianflone et al. ${ }^{(19)}$ discovered that following HAART, obese HIV-infected patients acquired fewer CD4+ T lymphocytes compared to normal weight HIV-infected patients, indicating that the potentially adverse immune response is associated with excess weight. ${ }^{(19)}$ However, the study of Tedaldi et al. ${ }^{(20)}$ found that higher BMI is not correlated with immunological and viral responses to antiretroviral therapy. ${ }^{(20)}$ Thus the effects of BMI on immune reconstitution after initiating HAART remain inconsistent.

The present study focused on patients with first-line ART and used BMI data that are easily calculated but important for predicting the outcome of ART treatment, treatment drop-out and CD4 recovery and death. The aim of this study was to determine the association of demographic factors, BMI and clinical staging with $\mathrm{CD}^{+}$counts that illustrate the progression of the disease in HIV patients seeking treatment using first-line antiretrovirals.

\section{METHODS}

\section{Research design}

An analytic research of cross-sectional design was conducted in West Papua (Manokwari Regency, Sorong Regency and Fak-Fak Regency) from May to July 2019.

\section{Study subjects}

The sample size was estimated using a 3\% level precision (d), estimated population proportion 0.98 with $95 \%$ confidence interval. Based on formula calculations the total sample to be taken in the three regencies was 251 persons. The respondents were HIV or AIDS patients who 
went to the voluntary counseling testing (VCT) clinics of Manokwari Hospital, Sele Be Solu Hospital (Sorong City), and Fak-Fak Regional Hospital in 2019 and who had received first-line ART for 6 months. The inclusion criteria of the study were availability of CD4 data and complete medical records, and having received ART for a minimum of 6 months and a maximum of 60 months. Female patients who were pregnant at baseline or during the follow-up visits were excluded from the study.

\section{Measurements}

Body mass index (BMI) was calculated using the formula weight (kilograms)/height (meters squared). The body mass index (BMI) in this study was also analyzed based on groupings from the Western Pacific Region of the WHO Criteria Pertaining to Obesity (WPRO criteria, 2000), namely underweight $(\mathrm{BMI}<18.5)$, normal BMI (18.5-22.9), overweight (BMI 2324 ,) obese I (25-29.9) and obese II (BMI=30). World Health Organization clinical staging: stage 1 , patients who are asymptomatic or have persistent generalized lymphadenopathy (lymphadenopathy of at least two sites [not including inguinal] for longer than 6 months) are categorized as being in stage 1 , where they may remain for several years. Stage 2, even in early HIV infection, patients may demonstrate several clinical manifestations. Clinical findings included in stage 2 (mildly symptomatic stage) are unexplained weight loss of less than 10 percent of total body weight and recurrent respiratory infections (such as sinusitis, bronchitis, otitis media, and pharyngitis). Stage 3 , as disease progresses, additional clinical manifestations may appear. Those encompassed by the WHO clinical stage 3 category (the moderately symptomatic stage) are weight loss of greater than 10 percent of total body weight, prolonged (more than 1 month) unexplained diarrhea, pulmonary tuberculosis, and severe systemic bacterial infections including pneumonia, pyelonephritis, empyema, pyomyositis, meningitis, bone and joint infections, and bacteremia. Stage 4, the WHO clinical stage 4 (the severely symptomatic stage) designation includes all of the AIDS-defining illnesses. ${ }^{(4)}$

\section{Laboratory analysis}

CD4 + cell examination uses the PIMA Analyzer (Alere), PIMA Bead Count and the PIMA CD4 cartridge. The CD4 value that comes out of the PIMA tool is an absolute value without a percentage value. As a priority, ART should be initiated in all individuals with severe or advanced HIV clinical disease (WHO clinical stages 3 or 4) and individuals with CD4 count $\leq 350$ cells/ $\mathrm{mm}^{3}$ (strong recommendation, moderate-quality evidence). The ART should be initiated in all individuals with HIV with a CD4 count of $>350$ cells $/ \mathrm{mm}^{3}$ and $\leq 500$ cells $/ \mathrm{mm}^{3}$, regardless of WHO clinical stage (strong recommendation, moderate-quality evidence)..$^{(21)}$

\section{Statistical analysis}

The independent variables were age (years), gender (M/F), education (years), occupation (yes/ no), body mass index and clinical stage, while the dependent (outcome) variable was the $\mathrm{CD}$ cell count. Data were analyzed using multiple linear regression with $95 \%$ confidence interval to quantify the strength of association between CD4 as the dependent variable and the independent variables. A p-value of less than 0.05 was considered significant.

\section{Ethical clearance}

This study has been approved by the Health Research Ethics Committee of the Board of Health Research and Development, Ministry of Health, Republic of Indonesia, under number LB.02.01/2/KE.008/2019.

\section{RESULTS}

Demographic characteristics of HIV research subjects include age, sex, occupation and education, while clinical characteristics include $\mathrm{BMI}$, clinical stage and $\mathrm{CD} 4^{+}$count. 
Table 1. Demographic and clinical characteristics of the subjects $(n=251)$

\begin{tabular}{lc}
\hline \multicolumn{1}{c}{ Characteristic } & $\mathbf{n}(\mathbf{\%})$ \\
\hline Age (median-range in years) & $36(15-72)$ \\
Sex (n\%) & \\
Male & $113(45)$ \\
Female & $138(55)$ \\
Education (n\%) & $2(8)$ \\
No schooling & $24(9.6)$ \\
Primary school & $40(15.9)$ \\
Junior high school & $106(42.2)$ \\
Senior high school & $79(31.5)$ \\
Bachelor & \\
Employment (n\%) & $41(16.3)$ \\
Government employee & $3(1.2)$ \\
Military/Police & $110(43.8)$ \\
Private employee & $3(1.2)$ \\
Sailor & $8(3.2)$ \\
Farmer & $7(2.8)$ \\
Laborer & $79(31.5)$ \\
Unemployed & \\
Body mass index (n\%) & $49(19.5)$ \\
Underweight & $100(39.8)$ \\
Normal weight & $37(14.7)$ \\
Overweight & $65(25.9)$ \\
Obese & $50(19.9)$ \\
Clinical stage (n\%) & $30(12)$ \\
Stage I & $161(64.1)$ \\
Stage II & $389(10-1500)$ \\
Stage III & \\
Stage IV & \\
CD4 count (median - range) & \\
\hline & \\
& \\
&
\end{tabular}

Table 1 shows that the subjects were of productive age, that the highest level of education was high school, and that almost half were private employees. Many HIV subjects were of normal weight, and had HIV/AIDS stage 3 .
Table 2 shows the results of the multiple linear regression analysis showing that the two variables that had a significant relationship with CD4+ count were BMI $(B=69.247 ; 95 \% \mathrm{CI}=$ 42.886-95.608) and clinical stage $(B=61.590$; 95\% CI=28.910-94.270). BMI was the most influencing factor for $\mathrm{CD} 4+(\beta=0.307)$ compared to clinical stage $(\beta=0.216)$.

\section{DISCUSSION}

Demographic characteristics of HIV respondents in West Papua indicate that the characteristics of gender, age, education and occupation are still dominated by women of productive age, secondary education level and private employment. In a previous study in Papua Province it was also found that most of the subjects were women, were of productive age (17-35 years) and had high school education. ${ }^{(22)}$

As to the clinical characteristics of West Papuan patients, the majority of patients have a CD4 count of $>350$ cells $/ \mathrm{mm}^{3}$, are in clinical stage 3 and have a normal body mass index of $18.5-22.9 \mathrm{~kg} / \mathrm{m}^{2}$. This is in contrast to a study in Timika (Mimika Regency) where more patients in stages 1-2 were found. ${ }^{(23)}$

From the results of the analysis it was found that there is a significant association between CD4+ count and body mass index of HIV patients in West Papua. The greater the BMI value, the higher the $\mathrm{CD} 4^{+}$count. The profile of nutritional changes in HIV patients has been reported to have changed since starting therapy,

Table 2. Factors associated with $\mathrm{CD}^{+}$lymphocyte resulting from multiple linear regression

\begin{tabular}{lccccc}
\hline \multirow{2}{*}{ Characteristics } & B & $\boldsymbol{\beta}$ & p value & Lower & Upper \\
\hline Sex & 6.304 & 0.156 & 0.120 & -13.632 & 16.975 \\
Age & 0.239 & 0.009 & 0.877 & -2.795 & 3.274 \\
Education & 12.568 & 0.050 & 0.432 & -44.048 & 18.912 \\
Employment & 2.493 & 0.024 & 0.718 & -11.112 & 16.098 \\
Body mass index & 69.247 & 0.307 & $0.000^{*}$ & 42.886 & 95.608 \\
Clinical stage & 61.590 & 0.216 & $0.000^{*}$ & 28.910 & 94.270 \\
\hline
\end{tabular}

B: unstandardized regression coefficient; $\beta$ : standardized regression coefficient 
with an increase in the prevalence of obesity and weight loss. Several studies have shown that the level of overweight found in people with HIV/ AIDS does not differ from the general population. ${ }^{(24)}$

Changes in body fat distribution, dyslipidemia and insulin resistance are common conditions in adult HIV patients undergoing antiretroviral therapy and being overweight can cause complications. ${ }^{(25-26)} \mathrm{A}$ decrease in BMI is associated with a worse prognosis in people with HIV. Body mass index is related to nutritional status of HIV sufferers, while nutritional status influences the function and immunity status of HIV patients. (27-28).

The poor immune function due to HIV/AIDS causes nutritional deficiencies resulting in immune dysfunction and accelerated disease progression to AIDS. ${ }^{(29)}$

Besides body mass index, another factor associated with $\mathrm{CD} 4+$ is the clinical stage of the disease. The analysis of HIV patients in West Papua found that the higher the clinical stage, the lower the CD4 + value. As many as $61.4 \%$ of HIV patients in West Papua are in clinical stage 3. Like CD4 counts, recognition of these clinical findings included in the WHO system is an important method for identifying HIV-infected individuals at high risk for morbidity and mortality. Remaining aware of the natural course of HIV infection allows one to base management decisions on the patient's clinical presentation. According to the WHO, advanced HIV/AIDS disease is defined for surveillance purposes as any clinical stage- 3 or stage- 4 disease or any clinical stage with a CD4 count greater than 350 per cubic $\mathrm{mm}$, and this information can be used to calculate the burden of disease and the demand for antiretroviral therapy. ${ }^{(5)}$ There is strong evidence supporting the clinical benefit of antiretroviral medications for adults with advanced HIV/AIDS as determined clinically or immunologically, with the WHO recommending definitive initiation of antiretroviral therapy in adults and adolescents in clinical stage 4, consideration of therapy initiation for those in clinical stage 3 , and antiretroviral use for those in clinical stage 1 or 2 only if the CD4 count is greater than 200 per cubic mm. For patients taking antiretroviral therapy for more than 24 weeks, new or recurrent clinical staging events can be a guide to decision-making. Prior to 24 weeks of antiretroviral treatment, clinical events are largely influenced by immune reconstitution or treatment toxicity and may not accurately reflect immune deterioration. ${ }^{(21)} \mathrm{WHO}$ guidelines report that the appearance of new or recurrent WHO clinical stage 3 and 4 conditions beyond 24 weeks after initiation of therapy suggests treatment failure. The HIV/AIDS epidemic clearly has broad and significant implications for individuals living around the globe. Populations in developing nations are especially hard-hit by HIV infection and, at the same time, frequently lack access to technological advances and other resources for diagnosing and managing care. Screening strategies, such as the WHO Clinical Staging System, allow for efficient identification of early infection and aggressive management when clinicians are equipped with the knowledge to apply them, and can therefore be useful tools for improving access to and implementation of care. A limitation of our study was its cross-sectional design. Staging at a single visit may not adequately capture events that might have occurred prior to the study evaluation. Also, the WHO clinical staging depends largely on gathering relevant clinical information from the patient and is therefore subjective.

The clinical implication of this study is that an absolute CD 4 cell count below 200 cells $/ \mathrm{mm}^{3}$ indicates severe damage to the body's immune system. Absolute CD4 cell counts can still be used to determine the initiation of antiretroviral therapy. Future studies should perform a CD4 percentage check in addition to an absolute CD4 count, because CD4 percentage is more stable than the absolute value.

\section{CONCLUSIONS}

Clinical stage and body mass index affect the absolute $\mathrm{CD}^{+}{ }^{+}$count; a greater $\mathrm{BMI}$ value 
will increase the $\mathrm{CD}^{+}$count and a higher clinical HIV stage will decrease the $\mathrm{CD} 4^{+}$count.

\section{CONFLICT OF INTEREST}

The authors declare that there is no conflict of interest.

\section{ACKNOWLEDGEMENT}

This work was partially supported by a grant from the Board of Health Research and Development, Ministry of Health, Republic of Indonesia. The authors are grateful to the VCTs of Manokwari, Sorong and Fak-Fak Health Agencies for their generous support.

\section{CONTRIBUTORS}

MW contributed to design of the study, sampling and performing the experiment; MIH and MLF interpreted the data. MW and EI contributed to writing the draft of the manuscript , DP and SA contributed to the revision and finalization the manuscript. All authors have read and approved the final manuscript.

\section{REFERENCES}

1. World Health Organization. HIV/AIDS : key facts. Geneva : World Health Organization;2020.

2. Kementrian Kesehatan RI. General situation of HIV/AIDS and HIV test. Jakarta: Pusat Data dan Informasi Kementrian Kesehatan RI; 2018.

3. Dinas Kesehatan Provinsi Papua Barat. Jumlah kasus HIV AIDS Papua Barat; 2016.

4. Weinberg JL, Kovarik CL. The WHO Clinical Staging System for HIV/AIDS. Virtual Mentor 2010;12:202-6. DOI: 10.1001/virtualmentor2010. 12.3.cprl1-1003.

5. Tsegaye AT, Wubshet M, Awoke T, Alene KA. Predictors of treatment failure on second-line antiretroviral therapy among adults in northwest Ethiopia: a multicentre retrospective follow-up study. BMJ Open 2016;6:e012537. doi: 10.1136/ bmjopen-2016-012537.

6. Seyoum A, Ndlovu P, Zewotir T. Quasi-Poisson versus negative binomial regression models in identifying factors affecting initial CD4 cell count change due to antiretroviral therapy administered to HIV-positive adults in North-West Ethiopia (Amhara region). AIDS Res Ther 2016;13:36. doi: 10.1186/s12981-016-0119-6.

7. Dalhatu I, Onotu D, Odafe S, et al. Outcomes of Nigeria's HIV/AIDS treatment program for patients initiated on antiretroviral treatment between 2004-2012. PLoS One 2016;11:e0165528. doi: 10.1371/journal.pone.0165528.

8. Koethe JR, Jenkins CA, Lau B, et al. Body mass index and early $\mathrm{CD} 4+\mathrm{T}$ cell revovery among adults initiating antiretroviral therapy in North America,1998-2010. HIV Med 2015;16:572-7. doi: 10.1111/hiv.12259.

8. Chakravarty J, Sundar S, Chourasia A, et al. Outcome of patients on second line antiretroviral therapy under programmatic condition in India. BMC Infect Dis 2015; 15: 517. doi: 10.1186/s12879015-1270-8.

10. Thao VP, Quang VM, Wolbers M, et al. Secondline HIV therapy outcomes and determinants of mortality at the largest HIV referral center in Southern Vietnam. Medicne (Baltimore) 2015;94:e1715. doi: 10.1097/MD.000000000000 1715.

11. Swain PK, Grover G. Determination of predictors associated with HIV/AIDS patients on ART using accelerated failure time model for interval censored survival aata. Am J Biostat 2016;6:12-9. DOI: 10.3844/ajbssp.2016.

12. Asiimwe SB, Kanyesigye M, Bwana B, Okello S, Muyindike W. Predictors of dropout from care among HIV-infected patients initiating antiretroviral therapy at a public sector HIV treatment clinic in sub-Saharan Africa. BMC Infect Dis 2016;16: 43. doi: 10.1186/s12879-0161392-7.

13. in ' $t$ Veld DH, Balestre E, Buyze J, et al. Determinants of weight evolution among HIVpositive patients initiating antiretroviral treatment in low resource settings. J Acquir Immune Defic Syndr 2015;70:146-54. doi: 10.1097/QAI. 0000000000000691 .

14. Baraki AG,Gezie LD, Zeleke EG, Awoke T, Tsegaye AT . Body mass index variation over time and associated factors among HIV-positive adults on second-line ART in northwest Ethiopia: a retrospective follow-up study. BMJ Open 2019; 9:e033393. doi:10.1136/bmjopen-2019-033393.

15. Tang AM, Sheehan HB, Jordan MR, et al. Predictors of weight change in male HIV-positive injection drug users initiating antiretroviral therapy in Hanoi, Vietnam. AIDS Res Treat 2011;2011:890308. doi: 10.1155/2011/890308. 
16. Li N, Spiegelman D, Drain P, et al. Predictors of weight loss after HAART initiation among HIVinfected adults in Tanzania. AIDS $2012 ; 26$ :57785. doi: 10.1097/QAD.0b013e32834f9851.

17. World Health Organization Regional Office for Europe. Body mass index - BMI. Copenhagen, Denmark : World Health Organization Regional Office for Europe;2020.

18. Koethe JR, Jenkins CA, Lau B, et al. Higher timeupdated body mass index: association with improved CD4+ cell recovery on HIV treatment. J Acquir Immune Defic Syndr 2016;73:197-204. doi: 10.1097/QAI.0000000000001035.

19. Crum-Cianflone NF, Roediger M, Eberly LE, et al. Impact of weight on immune cell counts among HIV-infected persons. Clin Vaccine Immunol 2011;18:940-6. doi:10.1128/CVI.00020-11.

20. Tedaldi EM, Brooks JT, Weidle PJ, et al. Increased body mass index does not alter response to initial highly active antiretroviral therapy in HIV-1infected patients. J Acquir Immune Defic Syndr 2006;43:35-41. doi: 10.1097/01.qai.0000234084. 11291.d4.

21. World Health Organization. Consolidated guidelines on the use of antiretroviral drugs for treatning and preventing HIV infection: recommendation for a public health approach. $2^{\text {nd }}$ ed. Geneva: World Health Organization;2016.

22. Widiyanti M, Hadi MI, Adiningsih S, et al. Demographic characteristics of the people living with HIV in Papua. J Heal Sci Prev 2019;3:10-5. DOI: http://doi.org/10.29080/jhsp.v3i1.175.
23. Widiyanti M, Ubra R, Fitriana E. Low body mass index increases risk of anemia in patients with HIV-AIDS receiving antiretroviral therapy. Univ Med 2017;36:221-7. DOI: 10.18051/UnivMed. 2017.v36.221-227.

24. de Araújo Mariz C, de Albuquerque MFPM, de Alencar Ximenes RA, et al. Body mass index in individuals with HIV infection and factors associated with thinness and overweight/obesity. Cad Saude Publica 2011;27:1997-2008. doi: 10.1590/s0102-311x2011001000013.

25. Lake JE, Currier JS. Metabolic disease in HIV infection. Lancet Infect Dis 2013;13:964-75. doi: 10.1016/S1473-3099(13)70271-8.

26. Duncan AD, Goff LM, Peters BS. Type 2 diabetes prevalence and its risk factors in HIV: A crosssectional study. PLoS ONE 2018;13:e0194199. doi: 10.1371/journal.pone.0194199

27. Crum-Cianflone N, Roediger MP, Eberly L, et al. Increasing rates of obesity among HIV-infected persons during the HIV epidemic. PLoS ONE 2010;5: e10106. doi:10.1371/journal.pone.0010106.

28. Thimmapuram R, Lanka S, Esswein A, Dall L. Correlation of nutrition with immune status in human immunodeficiency virus outpatients. Mo Med 2019;116:336-9.

29. Sicotte M, Langlois ÉV, Aho J, Ziegler D, Zunzunegui MV. Association between nutritional status and the immune response in $\mathrm{HIV}+$ patients under HAART: protocol for a systematic review. Systematic Reviews 2014 3:9. doi: 10.1186/20464053-3-9 